\title{
Responses of Annual Range Grasses and Legumes to Comparable Applications of Manurial and Inorganic Fertilizers
}

\author{
L.W. JOLLEY AND C.A. RAGUSE
}

\section{Abstract}

The use of cattle manure as an alternative to commercial inorganic fertilizer for annual rangelands was investigated, using mixtures of annual range grasses and legumes grown in pots containing a range soil known to be low in nitrogen and phosphorus and marginal in sulfur. Equivalent applications were made of $N, P$, and $S$ over a wide range of levels (ca $100-1,200 \mathrm{~kg} / \mathrm{ha} \mathrm{N}, 23-276 \mathrm{~kg} / \mathrm{ha}$ $P$, and $17-200 \mathrm{~kg} / \mathrm{ha} S$ equivalents) with the $N: P: S$ ratios of the inorganic fertilizer treatments adjusted to match those of the manure. All levels of both fertilizer types were applied either soil-incorporated or surface-broadcast. Plants were grown in greenhouse and outdoor environments, harvested twice, and separated into grass and legume components. Total yields and grass yields were higher for inorganic fertilizer. Clover yields were higher in the manure treatments, and in the outdoor environment, and increased from the first to the second harvests. Yields generally increased from first to second harvests and were higher in the outdoor environment. Mode of application had little effect on either yield or grass:legume ratio. Where economically feasible and available, the use of manures on rangeland may be justified, especially where enhancement of a legume component of the vegetation is desired.

The disposal of feedlot and dairy wastes is an important problem in this era of environmental concern and inflationary economy (Azevedo and Stour 1974; CAST 1975). The use of manure as a rangeland fertilizer may become increasingly attractive to those faced with increasing costs of commercial inorganic fertilizer, as well as to those directly concerned with regulations on the disposal of feedlot and dairy wastes.

Plant nutrient content of animal manures, at least of ruminant herbivores, is low compared to most commercially available inorganic fertilizers (Azevedo and Stout 1974; CAST 1975). In addition, elemental ratios and physical properties differ, including those which condition nutrient availability and mineralization rates (decay series) (Powers et al. 1975; Pratt et al. 1973; Pratt et al. 1976). The relatively slow release of at least part of the mineral nutrient composition of manure, its organic matter content, and presumed advantages in maintaining a favorable content of legumes in a mixed grass-legume community result in a comparative advantage for its use in marginal agricultural systems such as rangelands in low to moderate rainfall areas.

The objective of this study was to evaluate the response of several introduced species of annual range plants grown in mixtures in a range soil to beef feedlot manure and inorganic fertilizer when equivalent rates and ratios of three major nutrients (nitrogen, phosphorus, and sulfur) were applied over a wide range of levels.

\section{Materials and Methods}

Soil was collected from a range site at the University of California's Sierra Foothill Range Field Station, Yuba County, Califor-

Authors are range conservationist, USDA Soil Conservation Service, Bishop, California 93514, and professor, Department of Agronomy and Range Science, Univ. of California, Davis 95616.

Manuscript received October 17, 1979. nia. The series were of the Auburn-Sobrante-Los Posas association (Herbert and Begg 1969), classified as fine-loamy or fine, mixed, thermic families of Molic Haploxeralfs derived from metamorphosed basic igneous and meta-andesite rock. The soil was screened to remove rocks and other particles larger than $1 \mathrm{~cm}$, and $3.5 \mathrm{~kg}$ of soil was placed in each of 168 plastic pots $(18 \mathrm{~cm}$ diam).

The treatments compared applications of beef cattle manure vs. inorganic fertilizer. Both were either soil-incorporated or surfacebroadcast. Treatments were arranged factorially for five levels of manure application based on pot soil surface area; These were $5,600,11,200,22,400,33,600$, and $67,200 \mathrm{~kg} / \mathrm{ha}(2.5,5,10,15$, and 30 tons/acre). Nitrogen content of the feedlot manure (Kjeldahl analysis) was found to average $1.77 \%$. Phosphorus content was $0.41 \%$, as determined by the ammonium molybdate method of Watanabe and Olsen (1965). Sulfur content was not ascertained by analysis; a value of $0.30 \%$ was obtained from Azevedo and Stout (1974). Ammonium nitrate, triple superphosphate, and triple superphosphate with sulfur were applied in mixtures as necessary to match the N, P, and assumed S content and ratios of the manure. The above considerations resulted in the following array of treatment levels:

\begin{tabular}{cccc}
$\begin{array}{c}\text { Fertilizer level } \\
\text { manure equivalent } \\
\mathrm{kg} / \mathrm{ha} \\
(\text { ton } / \mathrm{ac})\end{array}$ & $\begin{array}{c}\mathbf{N} \\
\mathrm{kg} / \mathrm{ha} \\
(\mathrm{lb} / \mathrm{ac})\end{array}$ & $\begin{array}{c}\mathbf{P} \\
\mathrm{kg} / \mathrm{ha} \\
(\mathrm{lb} / \mathrm{ac})\end{array}$ & $\begin{array}{c}\mathbf{S} \\
\mathrm{kg} / \mathrm{ha} \\
(\mathrm{lb} / \mathrm{ac})\end{array}$ \\
\hline 5,600 & 99 & 23 & 17 \\
$(2.5)$ & $(89)$ & $(2 \mathrm{l})$ & $(15)$ \\
11,200 & 198 & 46 & 34 \\
$(5)$ & $(177)$ & $(41)$ & $(30)$ \\
22,400 & 397 & 92 & 67 \\
$(10)$ & $(354)$ & $(82)$ & $(60)$ \\
33,600 & 595 & 138 & 101 \\
$(15)$ & $(531)$ & $(123)$ & $(90)$ \\
67,200 & 1,189 & 276 & 202 \\
$(30)$ & $(1,062)$ & $(246)$ & $(180)$
\end{tabular}

The experimental design was a $2 \times 2 \times 5$ factorial of eight randomized blocks, each with a check in each block. Four of these blocks were moved outside the greenhouse following seedling establishment (February 9, 1976). The experiments were conducted during the period February through May when air temperature in the greenhouse ranged approximately from $20-30^{\circ} \mathrm{C}$.

Inoculated seeds of rose clover (Trifolium hirtum All. 'Hykon') and subterranean clover (Trifolium subterraneum L. 'Geraldton') were sown on January 24, 1976, in random arrangements of one row of each clover in each pot with one row each of annual ryegrass (Lolium multiflorum Lam.) and soft chess (Bromus mollis L. 'Blando'). Respective seeding rates for the four species were 70 , 112,21 , and $14 \mathrm{~kg} / \mathrm{ha}(62,100,19$, and $12 \mathrm{lb} / \mathrm{ac})$. After 2 weeks, plants were thinned to one-half the original seeding density of grass, and to one-third the original seeding density of clover. Pots were watered as necessary to maintain field moisture capacity. 
Table 1. Above-ground biomass (g/pot) of grass and clover components of mixtures grown under greenhouse and outside environments and fertilized with either steer manure or inorganic fertilizer. Data were combined as means $(n=40)$ of five application levels for two modes of application.

\begin{tabular}{|c|c|c|c|c|c|}
\hline \multirow[b]{2}{*}{ Location } & \multirow[b]{2}{*}{ Harvest } & & \multicolumn{3}{|c|}{ Dry Matter (g/pot) } \\
\hline & & & Manure & Inorganic & $\operatorname{LSD}(P=0.05)$ \\
\hline Greenhouse & First & $\begin{array}{l}\text { Grass } \\
\text { Clover } \\
\text { Total }\end{array}$ & $\begin{array}{l}0.65 \\
1.31 \\
1.96\end{array}$ & $\begin{array}{l}4.75 \\
1.23 \\
5.98\end{array}$ & $\begin{array}{l}.26 \\
.15 \\
.28\end{array}$ \\
\hline Greenhouse & Second & $\begin{array}{l}\text { Grass } \\
\text { Clover } \\
\text { Total }\end{array}$ & $\begin{array}{l}1.86 \\
2.50 \\
4.36\end{array}$ & $\begin{array}{r}9.44 \\
0.79 \\
10.23\end{array}$ & $\begin{array}{l}.48 \\
.38 \\
.61\end{array}$ \\
\hline Outside & First & $\begin{array}{l}\text { Grass } \\
\text { Clover } \\
\text { Total }\end{array}$ & $\begin{array}{l}1.47 \\
4.60 \\
6.07\end{array}$ & $\begin{array}{r}12.56 \\
4.07 \\
16.63\end{array}$ & $\begin{array}{l}.36 \\
.63 \\
.70\end{array}$ \\
\hline Outside & Second & $\begin{array}{l}\text { Grass } \\
\text { Clover } \\
\text { Total }\end{array}$ & $\begin{array}{r}4.42 \\
8.36 \\
12.78\end{array}$ & $\begin{array}{r}15.10 \\
4.15 \\
19.25\end{array}$ & $\begin{array}{r}.61 \\
.81 \\
1.11\end{array}$ \\
\hline
\end{tabular}

The greenhouse blocks were harvested March 6, 1976, and April 17, 1976. The outside blocks were harvested April 17, 1976, and May 29, 1976. Grass plants were clipped at $3 \mathrm{~cm}$ above the soil surface and clover plants immediately above the cotyledonary node.

The harvested grass species were combined, as were the clovers, and the composited samples wcre d ried to constant weight at $70^{\circ} \mathrm{C}$. Grass, clover, and total biomass data were subjected to analysis of variance and the means were separated using Duncan's new multiple-range test or the Least Significant Difference test.

\section{Results}

When averaged for all fertilizer level and application mode treatments, grass and total forage weights were significantly higher from the inorganic fertilizer treatments than from the manure treatments, both inside and outside the greenhouse (Table 1). Clover weights from the first harvest were not significantly different between fertilizers in either cnvironment, while the inorganic fertilizer treatment produced much less clover dry matter than did the manure treatment at the time of the second harvest for both greenhouse and outside replications. The highest average clover yield occurred at the second harvest of plants grown outside with manure and represented about two-thirds of the total yield per pot (Table 1).

Figure 1 shows grass and legume yield responses to increasing levels of fertilizer (inorganic vs. manure) for two successive harvests in two environments. Generally, increasing yields of grass were apparent as fertilizer levels were increased; these responses were not attenuated in the second harvest. The ratio of legume to grass was improved with time (higher in the second harvest for both environments) and with the higher light intensities and wider diurnal variations in ambient temperature present in the outdoor environment compared to the greenhouse. While total biomass yields were greatest when inorganic fertilizer was used, higher proportions of legume in the mixtures generally occurred when manure was applied. Visually, legumes were the dominant component in mixtures fertilized with manure at the second harvest in the outside

Table 2. Above-ground biomass of grass and legume components of mixtures grown under greenhouse and outside environments and fertilized with either steer manure or inorganic fertilizer. Data are means of eight replications for mode of application.

\begin{tabular}{|c|c|c|c|c|c|c|c|}
\hline \multirow[b]{2}{*}{ Application mode } & \multirow[b]{2}{*}{$\left(\mathrm{kg} / \mathrm{ha} \times 10^{4}\right)$} & \multicolumn{2}{|c|}{ Grass (g/pot) } & \multicolumn{2}{|c|}{ Clover (g/pot) } & \multicolumn{2}{|c|}{ Total (g/pot) } \\
\hline & & Harvest 1 & Harvest 2 & Harvest 1 & Harvest 2 & Harvest 1 & Harvest 2 \\
\hline \multicolumn{8}{|c|}{ Grown in greenhouse } \\
\hline Mixed & $\begin{array}{l}0.56 \\
1.12 \\
2.24 \\
3.36 \\
6.72\end{array}$ & $\begin{array}{l}1.45 \mathrm{a}+ \\
2.30 \mathrm{bc} \\
2.39 \mathrm{bc} \\
3.29 \mathrm{de} \\
2.89 \mathrm{~cd}\end{array}$ & $\begin{array}{l}1.60 \mathrm{a} \\
2.97 \mathrm{~b} \\
4.85 \mathrm{c} \\
7.55 \mathrm{~d} \\
8.05 \mathrm{de}\end{array}$ & $\begin{array}{l}1.12 \mathrm{ab} \\
1.31 \mathrm{ab} \\
1.30 \mathrm{ab} \\
0.99 \mathrm{a} \\
1.23 \mathrm{ab}\end{array}$ & $\begin{array}{l}2.20 \mathrm{dcf} \\
2.95 \mathrm{f} \\
1.83 \mathrm{cde} \\
0.81 \mathrm{ab} \\
1.12 \mathrm{abc}\end{array}$ & $\begin{array}{l}2.57 \mathrm{a} \\
3.61 \mathrm{bc} \\
3.69 \mathrm{bc} \\
4.28 \mathrm{~cd} \\
4.11 \mathrm{~cd}\end{array}$ & $\begin{array}{l}3.80 \mathrm{a} \\
5.92 \mathrm{bc} \\
6.67 \mathrm{bc} \\
8.3 \text { de } \\
9.16 \text { ef }\end{array}$ \\
\hline Broadcast & $\begin{array}{l}0.56 \\
1.12 \\
2.24 \\
3.36 \\
6.72\end{array}$ & $\begin{array}{l}\text { 1.93ab } \\
2.48 \mathrm{bc} \\
3.16 \mathrm{~d} \\
3.81 \mathrm{e} \\
3.32 \mathrm{de}\end{array}$ & $\begin{array}{lll}1.54 \mathrm{a} & & \\
3.02 \mathrm{~b} & & \\
5.73 \quad \mathrm{c} & \\
8.71 & \mathrm{e} \\
12.54 & & \mathrm{f}\end{array}$ & $\begin{array}{l}1.22 \mathrm{ab} \\
1.39 \mathrm{~b} \\
1.43 \mathrm{~b} \\
1.39 \mathrm{~b} \\
1.27 \mathrm{ab}\end{array}$ & $\begin{array}{l}1.66 \text { bcde } \\
2.52 \text { ef } \\
1.40 \mathrm{abcd} \\
1.30 \mathrm{abcd} \\
0.64 \mathrm{a}\end{array}$ & $\begin{array}{l}3.15 \mathrm{ab} \\
3.87 \mathrm{c} \\
4.59 \mathrm{de} \\
5.20 \mathrm{e} \\
4.59 \mathrm{de}\end{array}$ & $\begin{array}{l}3.20 \mathrm{a} \\
5.53 \mathrm{~b} \\
7.13 \mathrm{~cd} \\
10.01 \mathrm{fr} \\
13.18 \mathrm{~g}\end{array}$ \\
\hline \multicolumn{8}{|c|}{ Grown outside } \\
\hline Mixed & $\begin{array}{l}0.56 \\
1.12 \\
2.24 \\
3.36 \\
6.72\end{array}$ & $\begin{array}{l}2.75 \mathrm{a} \\
4.58 \mathrm{~b} \\
6.97 \mathrm{c} \\
9.08 \mathrm{de} \\
9.89 \mathrm{e}\end{array}$ & $\begin{array}{l}3.14 \mathrm{a} \\
5.14 \mathrm{~b} \\
8.22 \mathrm{c} \\
11.02 \mathrm{~d} \\
18.41 \mathrm{e}\end{array}$ & $\begin{array}{l}3.44 \mathrm{a} \\
4.13 \mathrm{a} \\
4.97 \mathrm{a} \\
4.89 \mathrm{a} \\
3.55 \mathrm{a}\end{array}$ & $\begin{array}{l}5.27 \mathrm{a} \\
7.47 \mathrm{bc} \\
7.78 \mathrm{bc} \\
6.23 \mathrm{ab} \\
5.18 \mathrm{a}\end{array}$ & $\begin{array}{l}6.18 \mathrm{a} \\
8.70 \mathrm{~b} \\
11.95 \mathrm{c} \\
13.96 \mathrm{~d} \\
13.44 \mathrm{~cd}\end{array}$ & $\begin{array}{l}8.42 \mathrm{a} \\
12.61 \mathrm{~b} \\
16.00 \mathrm{c} \\
17.25 \mathrm{c} \\
23.59 \mathrm{~d}\end{array}$ \\
\hline Broadcast & $\begin{array}{l}0.56 \\
1.12 \\
2.24 \\
3.36 \\
6.72\end{array}$ & $\begin{array}{ll}2.52 \mathrm{a} & \\
4.45 \mathrm{~b} & \\
8.31 & \mathrm{~d} \\
9.86 & \mathrm{e} \\
11.77 & \mathrm{f}\end{array}$ & $\begin{array}{l}3.49 \mathrm{a} \\
5.49 \mathrm{~b} \\
9.46 \mathrm{c} \\
11.96 \mathrm{~d} \\
21.25 \mathrm{f}^{2}\end{array}$ & $\begin{array}{l}3.81 \mathrm{a} \\
4.67 \mathrm{a} \\
4.72 \mathrm{a} \\
4.25 \mathrm{a} \\
4.93 \mathrm{a}\end{array}$ & $\begin{array}{l}4.69 \mathrm{a} \\
6.73 \mathrm{abc} \\
8.34 \quad \mathrm{c} \\
5.82 \mathrm{ab} \\
5.06 \mathrm{a}\end{array}$ & $\begin{array}{l}6.32 \mathrm{a} \\
9.12 \mathrm{~b} \\
13.03 \mathrm{~cd} \\
14.11 \mathrm{~d} \\
16.70 \mathrm{e}\end{array}$ & $\begin{array}{l}8.19 \mathrm{a} \\
12.21 \mathrm{~b} \\
17.81 \mathrm{c} \\
17.77 \mathrm{c} \\
26.31 \mathrm{~d}\end{array}$ \\
\hline
\end{tabular}

+ a,b,c, .. Treatments in the same column within an environment having the same letter are not significantly different $(P<0.05$, Duncan's new multiple range test). 

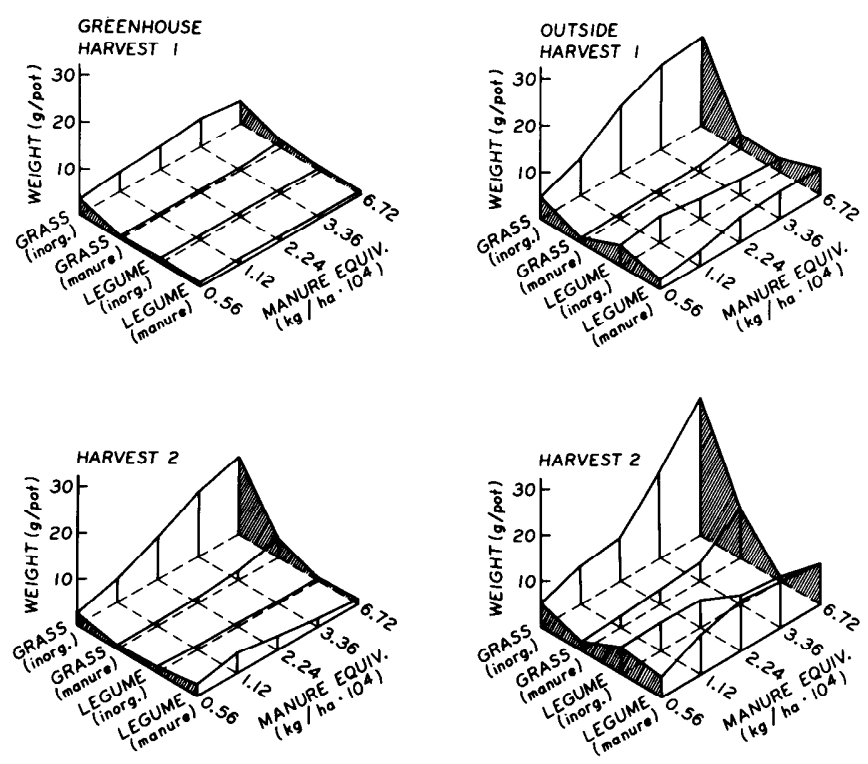

Fig. 1. Response curves for grass and legume above-ground biomass responses to increasing levels of NPS where fertilizer was applied as feedlot manure and inorganic fertilizer. Plants were grown as grasslegume mixtures in two environments.

\section{environment.}

Table 2 shows that statistically significant treatment responses within an environment were due principally to level of fertilization effects on the grasses, and not to mode of application. In the rare instances where significantly higher biomass yields due to mode of application were found, they were in favor of broadcast application. The general lack of significance for legume yields (Table 2) reflected the fertilizer-type interactions shown in Figure 1.

\section{Discussion}

When research is conducted with the plant elements of an agricultural ecosystem (such as the annual range system represented in the present study), the hazard of extrapolating directly from small field plots or greenhouse studies to the field at large is generally acknowledged. In this context, the present study had both advantages and disadvantages.

On the positive side, pot studies reduce in situ soil-related variability and enable use of an experimental design and replications sufficient to permit drawing valid conclusions. The present experiments were conducted in two environments at a time of year appropriate to provide the temperatures, irradiances, and photoperiods normally experienced in the field. Comparing results from two successive harvests of vegetative plant growth was more realistic than sampling accumulated, mature "peak standing crop" sampled at morphological maturity - in practice these plants are grazed during the growing season. Finally, a wide range of treatment levels was employed for the nutrient elements studied, with comparable ratios between the two nutrient sources.

On the negative side, while the surface arca and soil volume of an experimental unit were accurately known and precisely replicated, one cannot infer that equivalent levels of forage are produced in a similar space-time unit in the field; edge effect and differential rooting are two obvious sources of error. Also, major carryover effects for at least phosphorus have been well documented for annual range systems (Jones and Ruckman 1973), so few inferences can be drawn from the present experiment about field behavior in a time framc realistic (3-5 years) for management considerations.

Apart from the rapid and large grass response to inorganic fertilizer, the observed differential response of legumes between the two harvests is notable since it emphasizes the need to conduct either greenhouse or field trials over a period long enough to assess the eventual residual treatment response, which may be quite different from that initially observed. The results implicate grazing (defoliation) management as an important moderator of plant responses to different levels of nutrient availability over time.

In summary, the results support the use of cattle manures as rangeland fertilizer, especially where annual legume stand enhancement and stand persistence are desired. Availability, cost, logistics of transport and application, and "consumer acceptance" will determine the extent to which this logical recycling method will be employed.

\section{Literature Cited}

Azevedo, J., and P.R. Stout. 1974. Farm Animal Manures: An over-view of their role in the agricultural environment. Univ. Californaa Agr. Ext. Serv. Pub. Manual 44. 109 p.

CAST Report. 1975. Utilization of animal manures and sewage sludges in food and fiber production. Report No. 41 of the Council for Agricultural Science \& Technology. Headquarters: Dep. Agronomy, Iowa State Univ., Ames, Iowa 50010. 37.

Herbert, F.W., and E.L. Begg. 1969. Soils of the Yuba Area, California. Rep. of Coop. Proj., Dept. of Soils and Plant Nutr., UC-Davis and Yuba Co. 179 p.

Jones, M.B., and J.E. Ruckman. 1973. Long-term effects of phosphorus, sulfur, and molybdenum on subterranean clover pasture. Soil Sci. 115:343-348.

Powers, W.L., G.W. Wallingford, and L.S. Murphy. 1975. Research status on effects of land application of animal wastes. Environ. Protection Tech. Series. EPA-660/2-75-010. U.S. Gov. Print. Off. Washington, D.C. 20403. 21 p.

Pratt, P.F., F.E. Broadbent, and J.P. Martin. 1973. Using organic wastes as nitrogen fertilizers. Calif. Agr. 27:10-13.

Pratt, P.F., S. Davis, and R.G. Sharpless. 1976. A four-year trial with animal manures. I. Nitrogen balances and yields. II. Mineralization of nitrogen. Hilgardia 44:99-125.

Watanabe, F.S., and S.R. Olsen. 1965. Test of an ascorbic acid method for determining $P$ in water and $\mathrm{NaHCO}_{3}$ extracts from soil. Soil Sci. Soc. Amer. Proc. 29:677-678. 